Лобко М. М., канд. військ. наук, доцент

(ORCID 0000-0002-3848-8772);

Семененко В. М., канд. техн. наук, ст. наук. співроб. (ORCID 0000-0001-5774-0868); Фучко А. Й.

(ORCID 0000-0002-8941-2217)

Центр воєнно-стратегічних досліджень Національного університету оборони України імені Івана Черняховського, Київ

\title{
Деякі аспекти правового режиму воєнного стану в Україні: порядок введення та припинення дії
}

Резюме. На підставі аналізу вітчизняного законодавства, досвіду запровадження в Україні, публікацій науковців, експертів викладено сутність, зміст та основні положення правового режиму воєнного стану, порядок його введення та припинення дії. Законодавче врегулювання питання введення правового режиму воєнного стану має бути адаптовано до умов, які склалися під час російської збройної агресії проти України.

Ключові слова: правовий режим; воєнний стан, введення правового режиму воєнного стану; збройна агресія; воєнний конфлікт; збройний конфлікт; війна; заходи правового режиму.

Постановка проблеми. Останніми роками, на тлі російської збройної агресії проти нашої держави, певними українськими політиками, громадськими діячами, у засобах масової інформації час від часу порушуються питання щодо необхідності введення в Україні правового режиму воєнного стану. Водночас, як показала практика, законодавче врегулювання питання введення правового режиму воєнного стану не відповідало умовам, що склались під час російської збройної агресії проти України. Через це керівництвом держави було ініційоване внесення суттєвих змін до законодавства для правового забезпечення протидії збройній агресії РФ, зокрема й у питанні запровадження правового режиму воєнного стану.

Аналіз останніх досліджень та публікацій. 3 огляду на проведене дослідження випливає, що питанню запровадження правового режиму воєнного стану не приділялось належної уваги. Лише останнім часом у науковому та експертному середовищі часто виникають дискусії щодо цього питання [1-4]. Однак у цих дискусіях не рідко мають місце суб'єктивні судження, що висловлюються без опори на вітчизняне законодавство та міжнародне гуманітарне право, або розкривають його не в повному обсязі та дещо викривлено.

В умовах здійснення прихованої агресії РФ проти України, агресивних дій із застосуванням зброї у районі Керченської протоки та введення в Україні правового режиму воєнного стану в листопаді-грудні 2018 року, ці питання стали актуальними та набули практичного значення.
Мета статті. На основі проведеного аналізу положень вітчизняного законодавства та міжнародного гуманітарного права, досвіду запровадження в листопаді-грудні минулого року в Україні положення правового режиму воєнного стану, розкрити його сутність, мету, заходи, а також основні питання порядку його уведення та припинення дії.

Виклад основного матеріалу дослідження. Поняття "правовий режим воєнного стану" та "стан війни" безпосередньо пов'язані із загрозою або здійсненням збройної агресії проти однієї держави іншою державою (коаліцією держав).

У ст. 1 [5] наведено визначення "збройної агресії” як “застосування іншою державою або групою держав збройної сили проти України”. Зазначається, що збройною агресією проти України вважається будь-яка 3 таких дій:

вторгнення або напад збройних сил іншої держави або групи держав на територію України, а також окупація або анексія частини території України;

блокада портів, узбережжя або повітряного простору, порушення комунікацій України збройними силами іншої держави або групи держав;

напад збройних сил іншої держави або групи держав на військові сухопутні, морські чи повітряні сили або цивільні морські чи повітряні флоти України;

засилання іншою державою або від тї імені озброєних груп регулярних або нерегулярних сил, що вчиняють акти застосування збройної сили проти України, які мають настільки серйозний характер, що це рівнозначно переліченим в абзацах п'ятому- 
сьомому цієї статті діям, зокрема значна участь третьої держави у таких діях;

дії іншої держави (держав), яка дозволяє, щоб ii територія, яку вона надала в розпорядження третьої держави, використовувалася цією третьою державою (державами) для вчинення дій, зазначених в абзацах п'ятому-восьмому цієї статті;

застосування підрозділів збройних сил іншої держави або групи держав, які перебувають на території України відповідно до укладених 3 Україною міжнародних договорів, проти третьої держави або групи держав, інше порушення умов, передбачених такими договорами, або продовження перебування цих підрозділів на території України після припинення дії зазначених договорів.

Здійснення збройної агресії у вітчизняному та міжнародному законодавстві, у наукових публікаціях часто пов'язано 3 терміном “війна".

Водночас у воєнній сфері термін "війна" визначають як воєнний конфлікт. Так у ст. 1 [6] та п. 4 [7] наведені такі визначення, в основу яких покладено поняття “воєнний конфлікт":

воєнний конфлікт - форма розв'язання міждержавних або внутрішньодержавних суперечностей із двостороннім застосуванням воєнної сили. Основними видами воєнних конфліктів є війна та збройний конфлікт;

збройний конфлікт - збройне зіткнення між державами (міжнародний збройний конфлікт, збройний конфлікт на державному кордоні) або між ворогуючими сторонами в межах території однієї держави, як правило, за підтримки ззовні (внутрішній збройний конфлікт).

Війна, як форма розв'язання міждержавних суперечностей із двостороннім застосуванням воєнної сили, поділяється на локальну та регіональну.

На сьогодні існує значна кількість визначень “війна". Класичне визначення терміну "війна" можна сформулювати як складне специфічне суспільно-політичне явище зі своїми законами, яка ведеться всією державою i зачіпає всі сфери життя i діяльності країни [8-10]. Основною їі формою $\epsilon$ збройна боротьба, а головним і вирішальним засобом іiі ведення $є$ збройні сили та інші військові формування. У війні застосовуються також економічні, дипломатичні, ідеологічні, інформаційні й інші засоби та відповідні їм форми боротьби.
Локальна війна - війна між двома чи більше державами, у якій воєнні дії обмежені територіями воюючих держав та переслідують воєнно-політичні цілі, що зачіпають переважно інтереси лише цих держав (територіальні, політичні, економічні тощо).

Регіональна війна - війна, що охоплює певний регіон (частину континенту) за участю всіх чи більшості держав регіону та 3 метою досягнення воєнно-політичних цілей, що зачіпають інтереси цих держав.

Для збройного конфлікту характерним $є$ обмежене застосування збройних сил держав, що беруть у ньому участь. За цієї умови характерним буде у більшості випадків уведення правового режиму воєнного стану на територіях, де вестимуться воєнні дії.

Для війни, як форми воєнного конфлікту iз розв'язання міждержавних суперечностей за допомогою двостороннього застосування воєнної сили, частіше за все й буде притаманним уведення (тобто, на всій або на більшості іï територіï) правового режиму воєнного стану та стану війни. Такий підхід, у більшості випадків, $є$ притаманним й для України.

Говорячи про правовий режим воєнного стану слід вказати, що його визначення наведено у двох законах України. Зокрема, у ст. 1 [5] встановлене поняття "воєнного стану" як “особливий правовий режим, що вводиться в Україні або в окремих пї місцевостях у разі збройної агресії чи загрози нападу, небезпеки державній незалежності України, іiі територіальній цілісності та передбачає надання відповідним органам державної влади, військовому командуванню та органам місцевого самоврядування повноважень, необхідних для відвернення загрози та забезпечення національної безпеки, а також тимчасове, зумовлене загрозою, обмеження конституційних прав i свобод людини i громадянина та прав i законних інтересів юридичних осіб із зазначенням строку дії цих обмежень".

Питання визначення змісту правового режиму воєнного стану, порядку його введення та скасування, правових засад діяльності органів державної влади, військового командування, військових адміністрацій, органів місцевого самоврядування, підприємств, установ та організацій в умовах воєнного стану, гарантії прав і свобод людини і громадянина та прав i законних інтересів юридичних осіб встановлюються Законом України "Про правовий режим воєнного стану" [11]. У цьому законі також надається 
визначення “воєнного стану”. “Воєнний стан - це особливий правовий режим, що вводиться в Україні або в окремих іiі місцевостях у разі збройної агресії чи загрози нападу, небезпеки державній незалежності України, ऑii територіальній цілісності та передбачає надання відповідним органам державної влади, військовому командуванню, військовим адміністраціям та органам місцевого самоврядування повноважень, необхідних для відвернення загрози, відсічі збройної агресії та забезпечення національної безпеки, усунення загрози небезпеки державній незалежності України, i. територіальній цілісності, а також тимчасове, зумовлене загрозою, обмеження конституційних прав i свобод людини i громадянина та прав i законних інтересів юридичних осіб із зазначенням строку дії цих обмежень".

Проведення порівняння наведених у різних законах визначень показує, що вони за смисловим змістом практично ідентичні.

Досліджуючи сутність та зміст правового режиму воєнного стану слід зазначити, що, по-перше, воєнний стан це особливий правовий режим, який встановлюється в державі або в окремих іiі територіях. Уведення правового режиму надає особливі повноваження, тобто особливі права, органам виконавчої влади, військовому командуванню, органам місцевого самоврядування щодо повноважень, встановлених їм законодавством для мирного часу і створює необхідні умови для здійснення наданих їм цих особливих повноважень, а також концентрації необхідних ресурсів для забезпечення оборони держави.

По-друге, особливі повноваження органам державної влади, військовому командуванню, органам місцевого самоврядування потрібні для відвернення загрози або відсічі збройної агресї проти України.

По-третє, уведення правового режиму воєнного стану не означає оголошення війни. Воєнний стан - відповідь на існуючу загрозу суверенітету і територіальній цілісності та на збройну агресію.

По-четверте, уведення правового режиму воєнного стану передбачає тимчасове, зумовлене загрозою, обмеження конституиійних прав $i$ свобод людини i громадянина та прав i законних інтересів юридичних осіб із зазначенням строку дії цих обмежень.
По-п'яте, відповідно до сучасного міжнародного права введення воєнного стану державою, яка стала жертвою агресора, не буде перешкоджати наданню їй військової й інших видів допомоги.

По-шосте, $з$ уведенням правового режиму воєнного стану (наряду 3 мобілізацією) $y$ державі настає особливий період.

Особливий період - період, що настає 3 моменту оголошення рішення про мобілізацію (крім цільової) або доведення його до виконавців стосовно прихованої мобілізації чи 3 моменту введення воєнного стану в Україні або в окремих піi місцевостях та охоплює час мобілізації, воєнний час і частково відбудовний період після закінчення воєнних дій [5].

Уведення зазначеного правового режиму та настання особливого періоду надає підстави для застосування певних статей Кримінального Кодексу України, які $є$ притаманними для воєнного часу (наприклад, щодо ухилення від мобілізації, дезертирство, не виконання бойового завдання, мародерство та ін.).

Крім того, в умовах воєнного стану діють й інші особливості. Так, у період воєнного стану не можуть бути припинені повноваження Президента України, Верховної Ради України, Кабінету Міністрів України, Уповноваженого Верховної Ради України 3 прав людини, а також судів, органів прокуратури України, органів, що здійснюють оперативно-розшукову діяльність, досудове розслідування та органів, підрозділи яких здійснюють контррозвідувальну діяльність. Верховна Рада України в разі введення воєнного стану в Україні або окремих їі місцевостях продовжує працювати в сесійному режимі.

Зауважимо також, що в умовах воєнного стану забороняються зміна Конституції України, Конституції Автономної Республіки Крим, проведення виборів Президента України, а також виборів до Верховної Ради України, Верховної Ради Автономної Республіки Крим і органів місцевого самоврядування, проведення всеукраїнських та місцевих референдумів, проведення страйків, масових зібрань та акцій.

Нормативно-правові акти Верховної Ради Автономної Республіки Крим, рішення Ради міністрів Автономної Республіки Крим, рішення місцевих органів виконавчої влади та органів місцевого самоврядування, які стосуються прав i свобод людини i громадянина, що обмежуються у зв'язку 3 введенням воєнного стану, тимчасово не застосовуються.

Понад те, в умовах воєнного стану можуть встановлюватися окремі обмеження 
прав і свобод громадян із зазначенням строку дії цих обмежень.

Особливо слід додати, що відповідно до ст. 14 [5] в особливий період для керівництва виконанням заходів щодо оборони України рішенням Ради міністрів Автономної Республіки Крим, обласних державних адміністрацій, державних адміністрацій міст Києва та Севастополя утворюються ради оборони Автономної Республіки Крим, областей, міст Києва та Севастополя. До складу рад оборони крім посадових осіб місцевих органів виконавчої влади, органів місцевого самоврядування мають входити командири (начальники) військових частин Збройних Сил України, органів, військових частин інших військових формувань i правоохоронних органів розташованих на території області, міста. Положення про ради оборони затверджується Кабінетом Міністрів України.

Згідно з Положенням про раду оборони Автономної Республіки Крим і області одним iз завдань утворених рад оборони $\epsilon$ “вирішення питання щодо запровадження та здійснення в установленому порядку заходів правового режиму воєнного стану", для чого вони приймають відповідні рішення, які вводяться у дію розпорядженням голови відповідної ради оборони, згідно $з$ п. 4 [12].

Окремо варто зазначити, що відповідно до ст. 8[11] в Україні або в окремих ii місцевостях, де введено воєнний стан, визначені органи можуть запроваджувати та здійснювати (тобто, не автоматично, а за необхідності) ув межах встановлених тимчасових обмежень конституційних прав i свобод людини i громадянина та прав i законних інтересів юридичних осіб, заходи правового режиму воєнного стану передбачених відповідним указом Президента України про введення воєнного стану.

Згідно зі ст. 8 [11] визначені органи можуть запроваджувати та здійснювати певні заходи правового режиму воєнного стану основними 3 яких є:

встановлення посиленої охорони важливих об'єктів національної економіки та об'єктів, які забезпечують життєдіяльність населення, і вводити особливий режим їхньої роботи;

примусово відчужувати майно, що перебуває у приватній або комунальній власності, вилучати майно державних підприємств, державних господарських об'єднань для потреб держави в умовах правового режиму воєнного стану в установленому законом порядку;

запроваджувати комендантську годину (заборону перебування у певний період доби на вулицях та в інших громадських місцях без спеціально виданих перепусток і посвідчень) та встановлювати спеціальний режим світломаскування;

встановлювати особливий режим в’їзду і виїзду, обмежувати свободу пересування громадян;

перевіряти документи у осіб, а в разі потреби проводити огляд речей, транспортних засобів, багажу та вантажів, службових приміщень i житла громадян, за винятком обмежень, встановлених Конституцією України;

забороняти проведення мирних зборів, мітингів, походів і демонстрацій, інших масових заходів;

регулювати роботу підприємств телекомунікацій, поліграфічних підприємств, видавництв, телерадіоорганізацій, телерадіоцентрів та інших підприємств, установ, організацій i закладів культури та засобів масової інформації;

забороняти торгівлю зброєю, сильнодіючими хімічними i отруйними речовинами, а також алкогольними напоями та речовинами, виробленими на спиртовій основі; забороняти громадянам, які перебувають на військовому або спеціальному обліку у Міністерстві оборони України, Службі безпеки України чи Службі зовнішньої розвідки України, змінювати місце проживання (місце перебування) без дозволу військового комісара або керівника відповідного органу Служби безпеки України чи Служби зовнішньої розвідки України; обмежувати проходження альтернативної (невійськової) служби;

встановлювати для фізичних і юридичних осіб військово-квартирну повинність 3 розквартирування військовослужбовців, осіб рядового i начальницького складу правоохоронних органів;

проводити евакуацію населення, якщо виникає загроза його життю або здоров'ю, а також матеріальних i культурних цінностей, якщо виникає загроза їх пошкодження або знищення;

запроваджувати у разі необхідності нормоване забезпечення населення основними продовольчими і непродовольчими товарами, лікарськими засобами і виробами медичного призначення;

усувати 3 посад керівників підприємств, установ і організацій за неналежне виконання 
ними визначених цим Законом обов'язків та призначати виконувачів обов'язків керівників зазначених підприємств, установ і організацій; інші заходи.

Проведений аналіз уведення воєнного стану показує, що порядок його запровадження пов'язаний 3 проведенням низки правових процедур передбачених вітчизняним законодавством. Запровадження воєнного стану практично в усіх державах здійснюється вищими органами влади держави. Згаданим вище законом України [11] встановлюється порядок уведення воєнного стану в Україні. Пропозиції щодо уведення воєнного стану в Україні або в окремих іiі місцевостях на розгляд Президентові України подає Рада національної безпеки i оборони України. Пропозиції щодо залучення військових формувань i правоохоронних органів до здійснення заходів правового режиму воєнного стану розробляє та вносить на розгляд Ради національної безпеки i оборони України Генеральний штаб Збройних Сил України.

У разі прийняття рішення щодо необхідності введення воєнного стану в Україні або на окремих іï територіях Президент України видає відповідний указ i негайно звертається до Верховної Ради України щодо його затвердження та подає одночасно відповідний проєкт закону.

Указ Президента України про уведення воєнного стану в Україні або в окремих іiі місцевостях, затверджений Верховною Радою України, негайно оголошується через засоби масової інформації.

До того ж слід додати, що указ Президента України про введення воєнного стану в Україні або в окремих іiі місцевостях, затверджений Верховною Радою України, офіційно оприлюднюється разом із законом щодо затвердження такого указу Президента України та набирає чинності одночасно 3 набранням чинності таким законом.

В указі Президента України про введення воєнного стану згідно зі ст. 6 [11] зазначаються:

обгрунтування необхідності введення воєнного стану;

межі території, на якій вводиться воєнний стан, час введення i строк, на який він вводиться;

завдання військового командування, військових адміністрацій, органів державної влади та органів місцевого самоврядування щодо запровадження і здійснення заходів правового режиму воєнного стану;

завдання суб'єктам забезпечення цивільного захисту щодо приведення єдиної державної системи цивільного захисту, iii функціональних та територіальних підсистем у готовність до виконання завдань за призначенням в особливий період;

вичерпний перелік конституційних прав i свобод людини i громадянина, які тимчасово обмежуються у зв'язку з введенням воєнного стану із зазначенням строку дії цих обмежень та тимчасові обмеження прав і законних інтересів юридичних осіб із зазначенням строку дії цих обмежень;

інші питання.

Загальне керівництво запровадженням та виконанням заходів правового режиму воєнного стану здійснює Президент України.

Запровадження та здійснення заходів правового режиму воєнного стану покладаються на встановлені військові командування: Генеральний штаб Збройних Сил України, Об'єднаний оперативний штаб Збройних Сил України, командування видів Збройних Сил України, командування Сил спеціальних операцій Збройних Сил України, командування Десантноштурмових військ Збройних Сил України, управління оперативних командувань, командування з'єднань та військових частин Збройних Сил України, органи управління інших утворених відповідно до законів України військових формувань.

На територіях, на яких уведено воєнний стан, для забезпечення дії Конституції та законів України, забезпечення разом із військовим командуванням запровадження та здійснення заходів правового режиму воєнного стану, оборони, цивільного захисту, громадського порядку та безпеки, охорони прав, свобод i законних інтересів громадян можуть утворюватися тимчасові державні органи військові адміністрації.

Відповідно до п. 3, 4 ст. 4 [11] військові адміністрації населених пунктів утворюються в одному чи декількох населених пунктах (селах, селищах, містах), в яких сільські, селищні, міські ради та/або їхні виконавчі органи не здійснюють покладені на них Конституцією та законами України повноваження, у тому числі внаслідок фактичного саморозпуску або самоусунення від виконання своїх повноважень, або їх фактичного невиконання, або припинення їх повноважень згідно із законом.

У районі, області військові адміністрації утворюються у разі нескликання сесії відповідно районної, обласної ради у встановлені Законом України "Про місцеве самоврядування в Україні" строки або припинення їх повноважень згідно із законом, або для здійснення керівництва у сфері забезпечення оборони, громадського порядку i безпеки.

У разі прийняття рішення про утворення районних, обласних військових адміністрацій їх 
статусу набувають відповідно районні, обласні державні адміністрації, а голови районних, обласних державних адміністрацій набувають статусу начальників відповідних військових адміністрацій.

Рішення про утворення військових адміністрацій приймається Президентом України за поданням обласних державних адміністрацій або військового командування [11].

Спрямування, координацію та контроль за діяльністю обласних військових адміністрацій 3 питань забезпечення оборони, громадського порядку і безпеки, здійснення заходів правового режиму воєнного стану здійснює Генеральний штаб Збройних Сил України, а $з$ інших питань Кабінет Міністрів України у межах своїх повноважень.

У місцевостях, де ведуться бойові дії, запровадження та здійснення заходів правового режиму воєнного стану покладається безпосередньо на військове командування та військові адміністрації (у разі їх утворення).

До того ж, у [11] не встановлено, якими актами військове командування може самостійно або із залученням органів виконавчої влади, Ради міністрів Автономної Республіки Крим, органів місцевого самоврядування запроваджувати ті чи інші заходи правового режиму воєнного стану на встановлених для них територіях

У ст. 14 [11] у редакції 2012 року встановлювалось, що “органи, зазначені в цьому Законі та військове командування мають право видавати в межах своєї компетенції обов'язкові для виконання, у тому числі спільні, рішення, розпорядження, накази та директиви 3 питань запровадження та здійснення заходів правового режиму воєнного стану”. У зазначеному Законі у редакції 2017 і 2018 років, керівні акти встановлені тільки для начальника військової адміністрації (див. далі).

Водночас, у ст. 11 [5] встановлено, що Генеральний штаб Збройних Сил України “здійснює керівництво у сфері оборони та забезпечення громадського порядку в Україні або в окремих іi місцевостях, де введено воєнний стан у межах, визначених відповідним законом" (Закон України "Про правовий режим воєнного стану").

Згаданим вище Положенням про ради оборони [12] встановлено, що ради оборони на виконання покладених завдань приймають більшістю голосів рішення, які уводяться в дію розпорядженням голови ради.

Через це, доцільно було б законодавчо (або в указі Президента України про введення правового режиму воєнного стану) встановити акти, якими військове командування здійснює безпосереднє керівництво у місцевостях, де ведуться бойові дії та якими Генеральний штаб Збройних Сил України здійснює “спрямування, координацію та контроль” за діяльністю визначених місцевих органів виконавчої влади, військових адміністрацій, органами, силами i засобами інших військових формувань i правоохоронних органів із запровадження та здійснення заходів правового режиму воєнного стану і їх обов'язковість для виконання.

Такий підхід забезпечив би кореляцію 3 положенням пп. 8 п. 4 ст. 15 [11] згідно 3 яким “начальник військової адміністрації видає накази та розпорядження у межах своїх повноважень, які мають таку ж юридичну силу, що і рішення відповідної ради (рад). Накази, видані в межах повноважень місцевих рад, мають бути оприлюднені, крім тих, що містять інформацію 3 обмеженим доступом".

Слушно звернути увагу на те, що запровадження та здійснення заходів правового режиму воєнного стану проводиться відповідно до затвердженого Кабінетом Міністрів України Типового Плану запровадження та забезпечення заходів правового режиму воєнного стану в Україні або в окремих її місцевостях.

Участь у підготовці проєкту Типового плану запровадження та забезпечення правового режиму воєнного стану в Україні або окремих іï місцевостях бере Генеральний штаб Збройних Сил України. Проєкт зазначеного Типового плану розглядається Міністерством оборони України та подається на затвердження до Кабінету Міністрів України.

Отже, 3 наведеного випливає, що запровадження та здійснення заходів правового режиму воєнного стану визначених в указі Президента України, покладається на:

Президента України -загальне керівництво;

Ради оборони областей - безпосереднє керівництво у визначеній місцевості (через районні державні адміністрації та органи місцевого самоврядування);

Генеральний штаб Збройних Сил України:

здійснює спрямування, координацію та контроль за діяльністю обласних військових адміністрацій з питань забезпечення оборони, громадського порядку i безпеки, здійснення заходів правового режиму воєнного стану (3 інших питань здійснення заходів правового режиму воєнного стану покладається на Кабінет Міністрів України у межах своїх повноважень);

організовує підготовку та здійснює керівництво Збройними Силами України, 3'єднаннями, частинами та органами інших військових формувань і правоохоронних органів під час виконання ними заходів правового режиму воєнного стану;

організовує діяльність військових адміністрацій, командувань видів Збройних Сил України, управлінь оперативних командувань, 
командувань військових з'єднань та частин Збройних Сил України на території, на якій уведено воєнний стан;

військове командування та військові адміністрації (у разі їх утворення) безпосереднє керівництво у місцевостях, де ведуться бойові дії.

3 огляду на досвід, введення правового режиму воєнного стану у державі є непростою справою і потребує від виконавців відповідних знань, умінь i професійного фаху та організаторських здібностей. Уведення зазначеного правового режиму та здійснення визначених заходів потребує постійної підготовки суб'єктів його здійснення. Підготовку визначених суб'єктів до уведення правового режиму воєнного стану у державі доцільно проводити за допомогою періодичного проведення навчань (тренувань) та практичного відпрацювання найтиповіших заходів воєнного стану за розробленими сценаріями.

Дія воєнного стану на всій території України або в окремих ऑii місцевостях припиняється після закінчення строку, на який його було уведено. До закінчення строку, на який було уведено воєнний стан, та за умови усунення загрози нападу чи небезпеки державній незалежності України, іiі територіальній цілісності Президент України може прийняти указ про скасування воєнного стану на всій території України або в окремих іiі місцевостях, про що має бути негайно оголошено через засоби масової інформації. Прикладом цього є введення правового режиму воєнного стану в Україні в листопаді-грудні [14] та припинення його дії у грудні 2018 року.

Про припинення дії правового режиму воєнного стану в Україні, уведеного Указом Президента України від 26 листопада 2018 року № 393/2018, Президент України оголосив на засіданні Ради національної безпеки і оборони України 26 грудня 2018 року, що було оприлюднене засобами масової інформації.

Висновки. Таким чином, в умовах здійснення прихованої агресії РФ проти України питання уведення в Україні правового режиму воєнного стану стали актуальними та набули практичного значення.

Проведене наукове дослідження на основі аналізу положень вітчизняного законодавства та міжнародного гуманітарного права, досвіду запровадження в листопаді-грудні минулого року в Україні положення правового режиму воєнного стану дало змогу розкрити його сутність, мету та зміст заходів, а також основні питання порядку його введення та припинення дії.

Викладені у статті результати проведеного наукового дослідження щодо правового режиму воєнного стану дасть змогу системніше та цілеспрямованіше його запроваджувати органами виконавчої влади, органами місцевого самоврядування та органами військового управління, а також використовувати у навчальному процесі Національного університету оборони України імені Івана Черняховського й інших навчальних закладах.

Напрями подальших досліджень полягатимуть в удосконаленні законодавчого забезпечення питань запровадження положення правового режиму воєнного стану та розробленню рекомендацій органам державної влади у його реалізації за умов ескалації збройної агресії РФ проти України.

\section{СПИСОК ВИКОРИСТАНОЇ ЛІТЕРАТУРИ}

1. Черкес М. Ю. Міжнародне право. К., 2000.

2. С. Рахманін. Колаптоїдний воєнний стан, Дзеркало тижня від 1 грудня 2018 р. $00: 25 \mathrm{ZN}$ № 1221, 1 грудня - 7 грудня.

3. Арцибасов И. Н., Егоров С. А. Вооруженный конфликт: право, политика, дипломатия. - М., 1989.

4. Международное уголовное право. - М., 1995.

5. Закон України “Про оборону України”, (Відомості Верховної Ради України (ВВР), 1992, № 9, ст. 106).

6. Закон України "Про національну безпеку України, від 21 червня 2018 року № 2469-VIII, (Відомості Верховної Ради (ВВР), 2018. № 31, ст. 241).

7. 4. Воєнна доктрина України, (Указ Президента України від 24 вересня 2015 року №555/2015).

8. Военно - энциклопедический словарь, - М., Военное издательство, 1986.

9. Философский словарь, - М., Издательство политической литературы, 1987.

10. Вікіпедія, https://uk.wikipedia.org/wiki.

11. Закон України "Про правовий режим воєнного стану”, (Відомості Верховної Ради (ВВР), 2015, № 28, ст. 250 зі змінами).

12. Постанова Кабінету Міністрів України від 21.03.2007 p. № 507.

13. Закон України "Про особливості державної політики із забезпечення державного суверенітету України на тимчасово окупованих територіях у Донецькій та Луганській областях", (Відомості Верховної Ради (ВВР), 2018, № 10, ст. 54).

14. Указ Президента України від 26 листопада 2018 року № 393/2018 "Про введення воєнного стану в Україні. 
Лобко М. Н., канд. воен. наук, доцент;

Семененко В. М., канд. техн. наук, ст. науч. сотрудник;

Фучко А. Й.

Центр военно-стратегических исследований Национального университета обороны Украины имени Ивана Черняховского, Киев

Некоторые аспекты правового режима военного положения в Украине: порядок введения и прекращения действия

Резюме. На основании анализа отечественного законодательства, опыта внедрения в Украине, публикаций ученых, экспертов изложены сущность, содержание и основные положения правового режима военного положения, порядок его введения и прекращения действия. Законодательное урегулирование вопроса введения правового режима военного положения должно быть адаптировано к условиям, которые сложились во время российской вооруженной агрессии против Украины.

Ключевые слова: правовой режим; военное положение; введение правового режима военного положения; вооруженная агрессия; военный конфликт; вооруженный конфликт; война; меры правового режима.

\section{Lobko, PhD (Military), assistant professor;}

V. Semenenko, PhD (Technical), senior researcher;

A. Fuchko

Center for Military and Strategic Studies of the National Defence University of Ukraine named after Ivan Cherniakhovskyi, Kyiv

Some aspects of the legal regime of martial law in Ukraine: the procedure for introducing and terminating

Resume. Based on the analysis of domestic legislation, implementation experience in Ukraine, publications of scientists and experts, the essence, content and basic provisions of the legal regime of martial law, the procedure for its introduction and termination are described. The legislative settlement of the issue of introducing a legal regime of martial law should be adapted to the conditions that developed during the Russian armed aggression against Ukraine.

Keywords: legal regime, martial law; introduction of a legal regime of martial law; armed aggression; military conflict; armed conflict; war; measures of the legal regime. 